Miloš Jovanović ${ }^{1}$

BDD DIL BROKER AD Beograd
SCIENTIFIC REVIEW ARTICLE doi:10.5937/ekonomika1902099J

Received: May 14, 2019

Accepted: Jun, 28, 2019

\title{
INITIAL PUBLIC OFFERING AS A SOURCE OF FINANCING AND ITS SIGNIFICANCE FOR THE DEVELOPMENT OF THE SERBIAN CAPITAL MARKET
}

\begin{abstract}
Initial public offering has often been used in many economies in the privatization process of state-owned companies, primarily with those companies of strategic importance for the country. This further affected the private sector companies to decide on this step and thus gain additional capital in order to finance their further development. Based on the previous experience of many developed countries and countries in the region, the privatization through public offering of shares has significantly contributed to the development of the capital market in these countries, which is predominantly reflected in the growth of market capitalization, volume of turnover, number of transactions and participation of local and foreign investors in these markets. Through the conducted analysis of the capital market of Serbia, this paper points to its modest market capitalization and low level of liquidity largely caused by the long-term negligence of the role that the stock market can have on its development. The aim of the paper is to present the initial public offering of shares as a form of financing of companies, which can also make a significant contribution to the development of the Serbian capital market.
\end{abstract}

Keywords: initial public offering, capitalmarket, privatization, marketcapitalization.

JEL classification: F30, G24, G32

\section{ИНИЦИЈАЛНА ЈАВНА ПОНУДА КАО ИЗВОР ФИНАНСИРАњА И ЊЕН ЗНАЧАЈ ЗА РАЗВОЈ ТРЖИШТА КАПИТАЛА У СРБИЈИ}

\begin{abstract}
Апстракт
Иницијална јавна понуда се у многим економијама често користила y поступку приватизације државних предузећа, првенствено код оних компанија које су од стратешког значаја за земљу. То је касније утииало и на компаније у приватном сектору да се одлуче на тај корак и да на тај начин дођу до додатног капитала у ичиљу финансирања свог даљег развоја. На основу досадашњих искустава многих развијених земаља и земаља у окружењу, приватизација путем јавне понуде акција значајно је допринела развоју тржишта капитала у тим земљама, ито се првенствено огледа
\end{abstract}

${ }^{1}$ chemico.nis@gmail.com 
y расту тржишне капитализације, обиму промета, броју трансакција и учешћу домаћих и страних улагача на тим тржситима. На основу анализе тржишта капитала Србије, утврђена је скромна тржишна капитализацију $u$ низак ниво ликвидности, проузроковану првенствено дугогодишњим занемаривањем улоге коју берза може имати на његов развој. Циљ рада је да представи основне информације о иницијалној јавној понуди акиија као једног од облика финансирања компанија, који истовремено може дати значајан допринос развоју тржсишта капитала Србије.

Ključne reči: inicijalna javna ponuda, tržište kapitala, privatizacija, tržišna kapitalizacija.

\section{Introduction}

The financial market in Serbia is characterized by the inefficiency of the capital market and its potential in the overall financial system. Even after 20 years, being the duration of the transition process of the Serbian economy, we may conclude that Serbia still has an insufficiently developed and shallow financial market. Small volume of turnover, a minor number of listed financial instruments and a poor market capitalization are the main features of the capital market in Serbia. The capital market, as an important segment of the financial market (Krstić \& Đekić, 2018 ), was organized in the form of the traditional stock exchange back in 1989, which functioned until 2002 in a nonstandard manner. During this period, its functioning was limited to trade operations of short-term money loans in the form of debt instruments of companies (commercial notes and corporate bonds), treasury bills and bonds of the National Bank, while there was no trading in shares of companies in the prior period. Since 2002, the main financial instruments traded on the capital market have become the shares of the companies privatized accordance with the Law on Privatization from1997, as well as the bonds issued (emitted) for the purpose of pay of liabilities based on old foreign currency savings. With the reestablishment of the Belgrade Stock Exchange, the Securities Commission (1990) as a regulatory body that monitors the implementation of laws and by-laws regulating the financial market, the Central Registry (2002) and the adoption of a series of laws (the Law on Privatization, Law on Capital Market, Law on Takeover, Law on Business Companies, etc.) has been created an institutional framework for the growth and development of the capital market in Serbia.

\section{Characteristics of the Capital Market in Serbia}

Although the Serbian financial market meets all institutional, technical and legal conditions for the functioning of the capital market, we may say that it is not sufficiently developed or represented in the economic flows. The development of the capital market in the former socialist countries was largely influenced by the manner in which the company ownership transformation was carried out, which, in accordance with the applicable regulations at the time, turned public ownership into private. 
The selected privatization model has greatly influenced the development of the capital market, so we may conclude that the opportunity of a harmonized simultaneous process of privatization and development of the capital market has been missed in this area (of financial system). The applied privatization model also had a significant impact on the development of corporate culture, so we can conclude that it did not prove to be the best practice on this basis either. Selling majority packages of shares to one owner ensures budget revenues and improves the efficiency of the company in the first years after the sale, more than it would be achieved through voucher privatization, however leaves the capital market less developed than it would be under the alternative privatization schemes - for example, with voucher privatization. The Serbian authorities have chosen the method of selling majority packages of shares of the companies through auctions and public tenders as the dominant model of privatization (Prokopijevic, 2006), which resulted in a small number of listed companies on the Belgrade Stock Exchange whose shares are actively traded.

The liquidity of a market is reflected in the possibilities that it offers to its participants, to move easily and with as little cost as possible, from one form of financial asset to another. The capital market in Serbia is illiquid, which is reflected predominantly in a small volume of turnover at daily and annual basis, insufficient number of listed financial instruments and low market capitalization. In the last ten years, the only financial instruments that could be traded on the Belgrade Stock Exchange have been bonds of foreign currency savings of the Republic of Serbia (with the last bond to be billed matured on $31^{\text {st }}$ May 2016 and all bonds withdrawn from the market), long-term bonds of two banks that were also due with which the secondary trade was almost nonexistent, bonds of two local governments, debt securities issued by the Republic of Serbia and shares of privatized companies. One of the problems of the Serbian capital market is that, out of the total number of listed shares, there is only a small number of those which make a turnover during the year. The statistics illustrate that there are, on average, about twenty companies which trade shares daily, which is only a modest turnover compared to the developed markets in the region. During 2017, out of a total of 620 listed shares on the Belgrade Stock Exchange, the shares traded were only by 190 issuers. For these reasons, market capitalization is not an adequate indicator of the development of the capital market in Serbia, since a large number of privatized companies had to be on the stock market, as required by the law, although there was and there is still no interest of the investors for their shares because the majority packages of shares of these companies were sold through public tenders or auctions. Therefore, in recent years there has been a constant exclusion of securities and other financial instruments from the stock market. This is also illustrated by the indicator that in 2012, the total number of shares listed on the Belgrade Stock Exchange was 1067, while in 2017 there were 620 listed shares, which represents a decrease of $41.9 \%$ for a period of 5 years.

Since November 2015, there has been a group of long-term debt securities in dinars and euros issued by the Republic of Serbia included in the offer of financial instruments traded on the Belgrade Stock Exchange. One of the objectives of their introduction into regular trading on the Belgrade Stock Exchange was to enable individual investors to access these securities, providing them with an opportunity to place their assets in a simple way at significantly more favourable conditions compared to traditional savings. During 2017, the total number of listed bonds of the Republic of Serbia on the Belgrade Stock Exchange amounted to 70, while in the same year there were 58 different bonds traded. It should thus be noted that the dominant share in this trade belonged to the banking sector investors, bearing in mind the low yields that these financial instruments have had and relatively high trading costs that has further reduced the yield of the investors. 
The level of development of the capital market of a country is well illustrated by the ratio indicator that represents the relationship between the market capitalization and gross domestic product. In developed markets, this ratio is usually over $50 \%$, while in Serbia it is at the level of $15 \%$ (Table 1). We should also bear in mind that the amount of market capitalization of the Serbian capital market that was taken from the calculation of this ratio is not realistic, since in 2017, out of 620 listed companies on the Belgrade Stock Exchange, there were only 190 shares of companies traded, while 430 company shares were not traded at all.

Table 1: Ratio of Market Capitalization and GDP by countries in 2017.

\begin{tabular}{|c|c|c|c|c|}
\hline Country & GDP (billions \$) & $\begin{array}{c}\text { Market } \\
\text { Capitalization / GDP } \\
(\%)\end{array}$ & $\begin{array}{c}\text { Historical min. } \\
(\%)\end{array}$ & $\begin{array}{l}\text { Historical max. } \\
(\%)\end{array}$ \\
\hline USA & 19,75 & 139.8 & 35 & 149 \\
\hline China & 13,03 & 45 & 41 & 662 \\
\hline Japan & 4,85 & 158 & 56 & 361 \\
\hline Germany & 3,92 & 50 & 13 & 58 \\
\hline France & 2,82 & 89 & 52 & 182 \\
\hline United Kingdom & 2,81 & 117 & 47 & 201 \\
\hline India & 2,77 & 64 & 40 & 158 \\
\hline Italy & 2,23 & 15 & 10 & 45 \\
\hline Brazil & 2 & 49 & 26 & 106 \\
\hline Korea & 1,7 & 84 & 36 & 140 \\
\hline Canada & 1,65 & 119 & 78 & 190 \\
\hline Spain & 1,59 & 68 & 50 & 235 \\
\hline Russia & 1,58 & 1575 & 16 & 1575 \\
\hline Australia & 1,46 & 107 & 94 & 229 \\
\hline Mexico & 1,07 & 37 & 12 & 46 \\
\hline Indonesia & 1,07 & 38 & 17 & 99 \\
\hline Netherlands & 0,87 & 107 & 51 & 503 \\
\hline Switzerland & 0,68 & 269 & 84 & 431 \\
\hline Sweden & 0,55 & 134 & 63 & 159 \\
\hline Belgium & 0,46 & 110 & 80 & 147 \\
\hline Singapore & 0,34 & 122 & 92 & 418 \\
\hline Serbia & 0,04 & 15 & 12 & 55 \\
\hline
\end{tabular}

Source: The World Bank, www.theglobaleconomy.com, www.gurufocus.com

During the 1990s and early 2000s, company commercial papers and central bank treasury bills had a dominant role in the overall turnover in the financial market. After 2003, short-term instruments were redirected to the money market (interbank market), while the dominant assets on the Belgrade Stock Exchange according to of volume and number of transactions have been the company shares and bonds of foreign currency savings. Since 2002, the development of the capital market has been characterized by a dynamic increase in market capitalization and turnover all the way until 2007. Thereafter, there has been a drastic fall in turnover and market capitalization caused, primarily, by the effects of the global financial crisis and a significant withdrawal of foreign investors 
from the market, who have had a significant activity and share in the turnover of over $55 \%$ in that period (Hafner \& Krstić, 2013). In 2012, the turnover on the Belgrade Stock Exchange fell by $85 \%$ compared to the record year 2007, while in the same period, the market capitalization fell by $46 \%$. As of 2016 , there has been a significant increase in turnover which in 2017 has reached a level that is $168 \%$ higher than the turnover in 2012. However, such a significant increase in turnover on the stock exchange may occur exclusively due to the inclusion of long-term debt securities issued by the Republic of Serbia. The practice shows that these securities are primarily traded by banks and that this trading is done sporadically. The share turnover in the same period (2012-2017) was reduced by $60 \%$ (Table 2 ).

Table 2: Total Turnover on Belgrade Stock Exchange in period 2010-2017.

\begin{tabular}{|c|c|c|c|c|c|c|c|c|}
\hline & 2010 & 2011 & 2012 & 2013 & 2014 & 2015 & 2016 & 2017 \\
\hline $\begin{array}{l}\text { Total Turnover } \\
\text { ( mil. RSD) }\end{array}$ & 23.018 & 28.585 & 24.988 & 30.163 & 20.240 & 22.429 & 44.944 & 66.907 \\
\hline $\begin{array}{l}\text { Bonds of the } \\
\text { Republic of Serbia }\end{array}$ & 4.672 & 4.184 & 4.299 & 1.515 & 4.674 & 5.323 & 38.109 & 58.641 \\
\hline Company Shares & 18.294 & 24.400 & 20.505 & 28.490 & 15.564 & 17.106 & 6.465 & 8.266 \\
\hline $\begin{array}{l}\text { Corporate bonds } \\
\text { and municipals } \\
\text { bonds }\end{array}$ & 52 & 0 & 184 & 158 & 2 & 0 & 370 & 0 \\
\hline $\begin{array}{l}\text { Total } \text { Turnover } \\
(\%)\end{array}$ & $100 \%$ & $100 \%$ & $100 \%$ & $100 \%$ & $100 \%$ & $100 \%$ & $100 \%$ & $100 \%$ \\
\hline $\begin{array}{l}\text { Bonds of the } \\
\text { Republic of Serbia }\end{array}$ & $20,30 \%$ & $14,64 \%$ & $17,20 \%$ & $5,02 \%$ & $23,09 \%$ & $23,73 \%$ & $84,79 \%$ & $87,65 \%$ \\
\hline Company Shares & $79,48 \%$ & $85,36 \%$ & $82,06 \%$ & $94,45 \%$ & $76,90 \%$ & $76,27 \%$ & $14,38 \%$ & $12,35 \%$ \\
\hline $\begin{array}{l}\text { Corporate bonds } \\
\text { and municipals } \\
\text { bonds }\end{array}$ & $0,23 \%$ & $0,00 \%$ & $0,74 \%$ & $0,52 \%$ & $0,01 \%$ & $0,00 \%$ & $0,82 \%$ & $0,00 \%$ \\
\hline
\end{tabular}

Source: Belgrade Stock Exchange

There have been no serious foreign investors in our market to initiate a significant development of the capital market, for many reasons. The limiting factors for their higher activity in this market are mainly small number of different types of securities for trading and insufficient liquidity of the market. The liability on capital gains tax for the purchase of securities, which amounts to $15 \%$, and is paid both by the investors of investment and voluntary pension funds, and those with foreign currency savings deposits in banks, additionally affects the lack of interest of foreign investors, given the fact that many countries in the region do not have this type of tax. High trading costs in relation to the markets in the region represent another limiting factor. These costs significantly increase the transaction as the commissions of the stock exchange, stockbrokers, the Central Registry and the bank in the transaction balance range in the total amount up to $2 \%$. 


\section{Initial Public Offering as a Source of Financing and a Model of Transformation of the Company into a Public Joint-stock Company}

Initial Public Offering (IPO) is the first sale of shares of a company to the investment public. In this way, investors purchase shares in exchange for money, and the company through the primary capital market comes to the fresh money required for further growth and development (Denčič-Mihajlov,2013). Initial public offering is a transaction through which the company increases its value but also changes its ownership structure, that is, moves from any closed form to a publicly open joint-stock company. The IPO process is rather complex, demanding, and its realization lasts for several months, and therefore the issuers mostly rely on the services of the investment bank performing all business operations. The investment bank often acts as an underwriter as well, where the bank commits to purchase from the issuer all shares that are not sold on the market.

There are numerous advantages brought about by raising additional capital through the implementation of initial public offerings. With the additional capital, a companies increases its value, create conditions to finance its further development and improve their business, and the companie become more attractive for investors. At the same time, the companies improve its financial position on the basis of which they can obtain additional loans in the financial market under more favorable conditions. The possibility may appear for the company to be listed on the national stock market, which significantly contributes to: 1) the increase in the company's reputation, 2) increase of the interest in the company's shares by investors, 3) and increase of liquidity of the shares in the market, which enables purchase and sale of shares with minimal price deviations (Sjostrom \& William, 2001).

The main disadvantages of IPO includes high costs of public placement, where all services of the underwriter (the investment bank), lawyers, auditors, costs of registration of issuance and listing on the national stock exchange need to be settled. At the same time, the company becomes subject to regulatory body control and has additional costs. One of the important reasons why the current owners of companies do not choose initial public offerings but are additionally indebted and thus provide the necessary financial assets, is that the initial public offering brings about a significant change in the ownership structure of the company, it often gives way to the separation of ownership and management functions, hence the existing owners may have less decision making power in the company. Frequently, a major problem for the existing owners is the fact that the company must accept high corporate management requirements and transparency in business and reporting, if it decides to implement the IPO procedure and open the company towards the investment public.

Table 3: IPOs on the European Stock Exchanges in period 2015 - 2017.

\begin{tabular}{|c|c|c|c|c|c|c|}
\hline & \multicolumn{2}{|c|}{2015} & \multicolumn{2}{|c|}{2016} & \multicolumn{2}{|c|}{2017} \\
\hline Stock Exchange & $\begin{array}{l}\text { Number of } \\
\text { IPO }\end{array}$ & $\begin{array}{l}\text { Volume in } \\
\text { mil EUR }\end{array}$ & $\begin{array}{c}\text { Number } \\
\text { of IPO }\end{array}$ & $\begin{array}{l}\text { Volume in } \\
\text { mil EUR }\end{array}$ & $\begin{array}{l}\text { Number } \\
\text { of IPO }\end{array}$ & $\begin{array}{l}\text { Volume in } \\
\text { mil EUR }\end{array}$ \\
\hline $\begin{array}{l}\text { London } \\
\text { Exchange }\end{array}$ & 92 & 16.370 & 81 & 8.043 & 135 & 17.634 \\
\hline NASDAQ OMX & 90 & 5.905 & 80 & 7.861 & 98 & 3.996 \\
\hline Euronext & 46 & 11.228 & 23 & 3.455 & 20 & 3.258 \\
\hline $\begin{array}{l}\text { BME ( Spanish } \\
\text { Exchange) }\end{array}$ & 24 & 7.794 & 24 & 1.327 & 27 & 3.696 \\
\hline
\end{tabular}




\begin{tabular}{|c|c|c|c|c|c|c|}
\hline \multicolumn{4}{|c|}{ (с)Друштво економиста “Економика” Ниш } & \multicolumn{3}{|c|}{ http://www.ekonomika.org } \\
\hline SIX Swiss Exchange & 3 & 2.039 & 4 & 733 & 5 & 3.853 \\
\hline Deutsche Borse & 23 & 6.795 & 11 & 5.022 & 13 & 2.525 \\
\hline Borsa Instanbul & 6 & 42 & 2 & 103 & 3 & 278 \\
\hline $\begin{array}{l}\text { Oslo Bors \& Oslo } \\
\text { Axess }\end{array}$ & 8 & 1.078 & 6 & 287 & 11 & 1.099 \\
\hline Irish Stock Exchange & 2 & 394 & - & - & 3 & 3.756 \\
\hline Wiener Borse & 1 & - & 1 & - & 1 & 1.680 \\
\hline Warsaw & 33 & 440 & 28 & 262 & 27 & 1.811 \\
\hline $\begin{array}{l}\text { Zagreb } \\
\text { Exchange }\end{array}$ & 2 & 36 & - & - & - & - \\
\hline $\begin{array}{l}\text { Bucharest } \\
\text { Exchange }\end{array}$ & 5 & - & 2 & 51 & 4 & 256 \\
\hline Sofia & 1 & 6 & 2 & 31 & - & - \\
\hline Budapest & - & - & 1 & 9 & 1 & 73 \\
\hline Total: & 336 & 52.127 & 265 & 27.184 & 348 & 43.915 \\
\hline
\end{tabular}

Source: PWC: IPO Watch Europe Survey 2017, PricewaterhouseCoopers, London

The practice exercised by a large number of companies in the world shows that IPO is a much more favourable way of accessing additional capital than taking bank loans. The loan that the company would use for financing its development must be returned eventually, while by selling a smaller package of the existing or newly issued shares, the owner can still retain his majority ownership, i.e. its managerial rights, and at the same time provide the necessary resources for further growth and development of the company.

The statistics show that a significant activity was achieved in the IPO market globally, since the crisis in 2007. By the end of 2017, 1624 IPOs were registered in the total amount of US \$ 188.8 billion, representing a growth of $49 \%$ in the number of shares and $40 \%$ in the raised capital compared to year 2016. Although this activity on the market was not at the 2007 level (1974 IPOs, through which \$ 338.4 billion was invested), the investors predict a very active year of 2018 as the markets are slowly returning to levels before the crisis (Ernst \& Young, 2017).

Observed by the sectors in 2017, the dominant share was held by the financial sector, where EUR 16.7 billion were collected through 109 realized IPOs - the major IPO: Allies Irish Banks plc-2.9 billion eur. In the area of industrial production, close to EUR 7.9 billion were collected through the 50 realized IPOs - the major IPO: Landis\&Gyr Holding AG - EUR 2.08 billion, while in the consumer goods sector in 2017, EUR 6.4 billion were invested through 28 realized IPOs - the major IPO: Pirelli \& C SPA - EUR 2.3 billion eur (PWC, 2017).

On a global scale, the largest IPO activity is currently present in the Asian Capital Market. Companies from these areas dominate even if we examine the largest implemented initial public offerings throughout history. In the first five IPOs there is only one company from the US. Alibaba Group Holding Limited, (China) e-commerce company (currently one of the largest companies of this type in the world), which is currently holding the leading position as the company with the US \$ 25 billion collected, performed the greatest IPO in the world. 


\section{Importance of IPOs and Listing of Large Companies on the Level of Liquidity of the Capital Market in the Republic of Serbia}

In the 1990s, IPOs were often used in many economies in the privatization process of state-owned companies, primarily with those companies of strategic importance for the country. Most of the successful privatizations under this model have been carried out in Great Britain, France and other developed West European countries. In our region, examples of the state-owned company privatization through an IPO are: 1) the privatization of MOL in Hungary in 1995, when $42 \%$ of the capital was offered to the citizens, 2) the privatization of the Croatian INA in 2006, where investors were offered $16 \%$ of state shares, and 3) privatization of the Croatian Telecom in 2007, in which almost 360,000 citizens took part. Shortly after the IPO of Croatian state-owned companies, a series of IPOs continued in the private sector of food industry, shipbuilding, maritime transport and similar. These and many other examples of sales of shares in companies through public offerings of shares have significantly contributed to the development of capital markets in these countries, which is primarily reflected in the growth of market capitalization, volume of transactions, number of transactions and participation of local and foreign investors in these markets.

Serbia is one of few post-socialist countries which did not use IPO as a model of privatization during the transition. The main problem was a lack of political volition as well as a legal solutions in the field of finance (the Securities Market Act, Law on Business Companies, Law of Takeover of Joint stock Companies). By amending particular laws during 2012, the conditions were met for initial public offerings to be technically feasible on the capital market in Serbia. After two decades of transition, there are still around 1300 state-controlled companies in Serbia (large public enterprises, public local companies, social enterprises in the process of privatization) with about 450 thousand employees, representing over $15 \%$ of the total number of formal employees. The implementation of IPOs with public companies should not be understood solely as one of the models of their privatization, but also as a way through which companies gain new capital, where a larger number of shareholders with their interest in business results, enter the company, further leading to the professionalization of management. A major missed chance for the development of the Belgrade Stock Exchange lies in the fact that Naftna Industrija Srbije and Airport "Nikola Tesla", as companies of general public interest and with great market capitalization, were not privatized through initial public offerings. One of the key problems that delay the growth of the capital market in Serbia is the absence of large state-owned companies from the stock market. Given that these are mainly companies of general public significance, it can objectively be assumed that the state will be interested in retaining a part of the ownership under direct control, bearing in mind their importance and the possibility of influencing the overall economic development of the country. At the same time, the further development of these companies requires the injection of fresh capital. The privatization of certain public companies and companies controlled by the country of Serbia (Elektroprivreda Srbije, Telekom, Srbijagas, Putevi Srbije, etc.) through the implementation of the initial public offerings represents a way for the state to fulfil the above mentioned key requirements while providing, at the same time, local and foreign professional and individual investors with investments in attractive securities. The influence of the listing of public companies onto the liquidity of the capital market in the Republic of Serbia is best illustrated by the examples from years 2010 and 2011, when the Belgrade Stock Exchange started trading with the shares of Naftna Industrija Srbije and shares of Airport "Nikola Tesla". Listing of issuers with multi-million number of shares has significantly contributed to the increase in the volume of turnover, number 
of concluded transactions on the stock exchange and participation of foreign investors in the total turnover.

With the implementation of IPOs of the major Serbian public companies and inclusion of their shares in the Belgrade Stock Exchange, investors would be given a greater opportunity to invest in quality securities. The more massive use of IPO as a form of financing of companies, listing of their shares on the stock exchange and organization of secondary trading, would contribute to strengthening of local institutional investors, better interest of foreign investors and overall development of the domestic capital market. Initial public offerings of public and major companies' shares in Serbia are most likely the last chance for the development of the capital market. For the success of the foremost IPOs, it is also important to enter one of the leading European stock exchanges. This would greatly increase the availability of securities to foreign investors, thereby increasing their liquidity not only on the foreign, but also on the Belgrade Stock Exchange. In addition, listing of securities on the foreign exchange would be a sign that the issuer meets strict listing criteria, which gives confidence both to foreign and local investors.

What is perhaps most important is that initial public offerings enable a large number of citizens to take part in issuance, as we need to bear in mind that the Serbian population represents a potential of ten billion euros.

\section{Conclusion}

The capital market in Serbia is characterized by poor liquidity, a small number of listed quality securities with constant trading and symbolic turnover in relation to the developed stock exchanges of the world. For these reasons, the paper points out the necessity to follow contemporary financial trends and exercise positive and established practice of the developed countries' markets in the financial market of Serbia. Implementation of initial public offerings of many public companies, as well as private companies in Serbia, is a necessary condition for a substantial development of the capital market. Through the IPO procedure, shares are offered to the widest investment public and by organizing their secondary trade on the Belgrade Stock Exchange, it will significantly contribute to solving the problem of the chronic lack of quality securities on the organized capital market.

\section{References}

Arsić, M. (2012). Reforme državnih i društvenih preduzeća. Kvartalni monitor FREN, (28), $72-82$.

Benninga, S., Helmantel, M., \& Sarig, O. (2005). The timing of initial public offerings. Journal of financial economics, 75(1), 115-132.

Bernstein, S. (2015). Does Going Public Affect Innovation?. The Journal of finance, 70 (4), 1365-1403.

Chemmanur, T., Hu,G., \& Huang , J. (2010). The Role of Institutional Investors in Initial Public Offerings. The Review of Financial Studies, 23 (12), 4496-4540.

Denčič-Mihajlov, K. (2013). Zašto dolazi do potcenjenosti akcija iz inicijalne javne ponude?. Teme, 37(1), 163-182. 
Derrien F., \& Kecskes, A. (2007). The Initial Public Offerings of Listed Firms. The Journal of finance, 62 (1), 447-479.

Dewenter, K., \& Malatesta, P. (1997). Public Offerings of State Owned And Privately Owned Enterprises: An International Comparison. The Journal of finance, 52 (4), 1659-1679.

Draho, J. (2005). The IPO Decision: Why and How Companies Go Public. Northampton, Edward Elgar Publishing Ltd.

Ernst \& Young, (2017). Global IPO Trends: Q4 2017, Retrieved from: https:// www.ey.com/Publication/vwLUAssets/ey-global-ipo-trends-q4-2017/\$FILE/eyglobal-ipo-trends-q4-2017.pdf, Accessed on: 15 October 2018.

Geddes, R . (2011). An Introduction to Corporate Finance: Transactions and Techniques. New York, John Wiley \& Sons Ltd.

Hanley, K.W., \& Hoberg, G. (2012). Litigation risk, strategic disclosure and the underpricing of initial public offerings. The Journal of finance, 103(2), 235-254.

Hafner, P., \& Krstić, M. (2013). Svetska ekonomska kriza i koncepti postkriznog razvoja, Ekonomika, 59(4), 76-85

Jeremić, N., \& Lika, S. (2015). Privatizacija preduzećaza telekomunikacije Telekom Srbija ad Beograd u svetlu sumnje u efikasno korporativno upravljanje, Univerzitet Singidunum - Međunarodna naučna konferencija FINIZ , 148-154.

Krstić, M., \& Đekić, I. (2018). Bihevioralna ekonomija i standardna ekonomska teorija. Kultura polisa, (37), 397-410

Pavlović, V., \& Muminović, S. (2010). Značaj razvoja finansijskih tržišta za srpsku privredu. Industrija, 38 (4), 41-67.

Prokopijević, M. (2007). Tržište kapitala u Srbiji, Zbornik Instituta za evropske studije.

Prokopijević, T., Mladenović, M., \& Mihajlović, R. (2016). Municipalne obveznice lokalne samouprave. Ekonomika, 62(4), 175-182.

PWC, (2017). IPO Watch Europe Survey 2017, PricewaterhouseCoopers, London, Retrieved from:https://www.pwc.co.uk/audit-assurance/assets/pdf/ipo-watcheurope-2017-annual-review.pdf, Accessed on: 22 October 2018.

Ragozzino, R., \& Reuer, J. J. (2007). Initial public offerings and the acquisition of entrepreneurial firms. Strategic Organization, 5(2), 155-176.

Ritter, J. (1991). The Long Run Performance of initial Public Offering. The Journal of finance, 46(1), 3-27.

Ritter, J., \& Zhang D. (2007). Affiliated mutual funds and the allocation of initial public offerings. The Journal of finance, 86(2), 337-368.

Sjostrom, Jr., \& William K. (2001). Going Public Through an Internet Direct Public Offering: A Sensible Alternative for Small Companies?. Florida Law Review, 53(), 529-566. 